\title{
GRAMMATICAL ASPECTS OF LEGAL TRANSLATION
}

\author{
Bailo I. Ya, Bilobrova O. V. \\ National University "Odesa Law Academy”
}

The paper analyses the following grammatical features of legal text translation. The research substantiates the necessity and urgency of studying the problems of grammatical units translation in legal discourse in the context of international relations globalization. The paper considers different approaches to the understanding of grammatical features in the translation of the legal text, the main characteristics of an institutional legal text: brevity, uniformity, logic and argumentation, impersonality, accuracy of wording, conservatism, utmost clarity of statements, and established macrostructure of individual text genres.

The article looks into the problem points associated with the nature of legal discourse and the specific features of English and Ukrainian legal systems and languages. Namely these are the issues associated with differences in the structure of languages; the range of their grammatical categories, forms and constructions; the difficulties with sentence construction; complexity caused by the use of an unusual sentence structure in the English-language legislative discourse. The most commonly used grammatical transformations in the translation of legal texts are classified: replacement of the singular with the plural, replacement of parts of speech, change of word order in a sentence, translation of gerund constructions, sentence division, and combining of sentences.

As a result of the research, the authors arrive at the conclusion that the study of linguistic grammatical features is the basis for the textual arrangement of legal texts and paperwork. Thus, the following general conclusions are formulated: translation solutions related to grammatical problems of translation include both variant correspondences and different types of transformations, including complex one-and multi-level compensations. It is determined that the considered examples, grammatical transformations and knowledge of features of the legal text structure are important translation tools to adequately convey the information content of the text. It is also established that legal translation cannot be done correctly either with the use of special knowledge in the relevant field of law or with the knowledge of the specifics of a particular type of legal relationship.

Key words: grammatical features of legal text translation, grammatical construction, grammatical transformation, problem points, range of grammatical categories, forms and constructions.

Байло І. Я., Білоброва О. В. Граматичні аспекти юридичного перекладу. У роботі досліджено граматичні особливості перекладу юридичного тексту. Обгрунтовано необхідність та актуальність вивчення проблем перекладу граматичних одиниць в юридичному дискурсі в умовах глобалізації міжнародних відносин. Розглянуто різні підходи вчених до розуміння граматичних особливостей перекладу юридичного тексту та основних характеристик інституиійного юридичного тексту, серед яких: стислість, уніфікованість, логічність і аргументованість викладу, безособовість, точність формулювань, консервативність, гранична чіткість висловлювань, усталена макроструктура окремих текстових жанрів.

У пропонованій статті проаналізовано труднощі, пов'язані з природою юридичного дискурсу та специфічними рисами англійської та української правових систем і мов, а саме: труднощі, пов'язані з розбіжностями в будові мов, наборі їхніх граматичних категорій, форм та конструкиій; труднощі з побудовою речення; трудноші, спричинені використанням незвичайної структури речень в англомовному законодавчому дискурсі. Виокремлено найбільш уживані граматичні трансформації при перекладі текстів юридичної тематики, зокрема: заміну однини множиною, заміну частин мови, зміну порядку слів у реченні, переклад герундіальних конструкиій, членування речення, об'єднання речень.

Резюмовано, щзо вивчення мовних граматичних особливостей є базою для текстового оформлення юридичних текстів і документів; перекладаџькі рімення, пов'язані з граматичними проблемами перекладу, включають як варіантні відповідності, так і різні види трансформацій, зокрема й комплексні одно- $і$ різнорівневі компенсації. Визначено, щзо розглянуті приклади, граматичні перетворення й знання особливостей структури юридичного тексту є важливими інструментами перекладу для адекватної передачі інформаційного змісту тексту. 3'ясовано, щзо юридичний переклад не може бути коректним без використання спеціальних знань у відповідній галузі права, без знання специффіки конкретного виду правовідносин.

Ключові слова: граматичні особливості юридичного перекладу тексту, граматична конструкція, граматична трансформація, труднощі, діапазон граматичних категорій, форми та конструкції.

Target setting and substantiation of the urgency of its consideration. Translation is the process which considers comprehension of the sense of a text or a particular discourse belonging to the native speaker of one country by the recipient of another country and the mutual intercultural and linguistic exchange between these subjects. Nowadays, all countries of the world are involved in the process of globalization. We are all interdependent and there is a tendency to mutual enrichment and exchange of ideas and projects, to integration and adaptation of Ukrainian legislation to the European legal system. 
Translation of legal documents, including laws and regulations, becomes a necessity, and therefore the study of the peculiarities of legal discourse translation is becoming increasingly important. Cooperation is inevitable in the context of strengthening international ties and thus, in favour of better understanding among speakers of different languages, it appears completely impossible to do without adequate translation. In their practical or scientific activities, public authorities, organizations, enterprises, companies, as well as individuals and legal entities are somehow related to the legal aspect of documentation, correspondence, legal framework, international agreements, contracts, as well as their subsequent translation in interaction with foreign persons. Moreover, the adaptation of the national legislation to the European standards, understanding of foreign media sources, scientific publications and the conclusion of private and international agreements and treaties requires accurate, logical and correct translation, which would take into account the grammatical features of languages. Therefore, in the complex translation of the text of legal issues, the grammatical component is regarded as an extremely important integral part of legal translation. Without it, it is impossible to adequately understand the language of the native speaker. Accurate grammatical construction and grammatical transformation being as close as possible to the authenticity of the original source are a key factor in translation activities. This paper pays special attention to the grammatical features of the translation of a legal text. After all, the study of the grammatical aspect of translation of documentation belonging to the legal discourse remains insufficiently studied.

Legal discourse is a type of institutional discourse that belongs to the sphere of social relations regulation and characterized by a rigid organizational and hierarchical structure. Traditionally, the following main types of legal discourse are distinguished: 1) legislative; 2) oral judicial; 3) written judicial; 4) educational legal. Professional lawyers are the source of legal texts; they create these texts, taking into account the peculiarities of society.

The status of law is extremely high and crucial; its language is a reliable indicator of the legislators' level of culture and their respect for citizens. When formulating laws, their authors (and hence translators) are simply obliged to adhere to the existing language norms. The general linguistic characteristics of legislative discourse in English and Ukrainian have much in common.

The language of legislative discourse is usually ritual and archaic; it is subject to very strict stylistic norms regarding the way of expression and register, as well as highly codified genre structures. The style of most documents should not evoke additional associations and distract attention from the essence of the document; there are no peculiar individual authorial features in this style. Neutral presentation of legal norms increases the effectiveness of legal regulation.

Analysis of recent researches and published works. Linguistic researchers of the legal text have substantially contributed to the study of grammatical features of text translation in the legal discourse.
According to I. Semyonkina, there are strict restrictions at all levels, from the macrostructure of the text to paragraphs, sentences and phrases, with an effort to adhere to standardized forms, which are infrequent in ordinary texts, clichés, set expressions and special means of expressing integrity (coherence, intertextuality) [6].

The language of law is conservative because archaisms add authority and, moreover, majesty, to it. The complexity of information load of each sentence and the importance of complete and unambiguous transmission of each position, when any possibility of ambiguous interpretation is excluded, lead to the use of extremely long sentences with complex syntax, high level of hypotaxis, and repetition of syntactic discontinuity, i.e., logical structures with the meaning of condition and reason are frequent in use.

According to the researches of S. Postrikhan, the legal text is an example of a business culture focused on a certain circle of recipients. Such a document is characterized by a pragmatic orientation, due to the specific format of lexical and grammatical units, logical and legal connections [4].

The researchers of the legal text I. Korunets and S. Postrigan define legal translation as a highly specialized approach of a translator, who must have knowledge in the field of jurisprudence and law. For an adequate transmission of legal information, the language of the legal translation must be particularly accurate, logical, reasonable, clear, reliable, etc. [3; 4]. I. Rud connects in his studies the use of clichés with the format of contracts and agreements with a strict clear structure [5, 222-225]. O. Emelina defines the role of present tense verbs and passive constructions, emphasising on the use of clichéd forms of translation [2].

Striving to be as accurate as possible, lawyers prefer a tried-and-true, flexible, vague, and abstract language. The objectivity of information presentation is ensured by the predominance of the absolute present tense of the verb and passive constructions. Compressive language components are not inherent in the legal text (abbreviations, parentheses and numerical notations are not characteristic; numerals are usually denoted by words, etc.).

The general nature of information is conveyed due to the predominance of the semantics of the subject, where, along with nouns of legal subject, nouns and pronouns with generalizing semantics (everyone, no one, all citizens) are widely used.

The imperative nature of information is provided by the use of verb structures with the meaning of the modality of necessity and the modality of possibility: may, has the right. Legal information to be translated may relate to any area of human activity, and this may present additional difficulties for the translator.

In such a situation, in addition to background knowledge in the legal field (understanding the realities of different legal systems, special terminology, cultural and historical context, etc.), the translator needs to demonstrate background knowledge in the specific field to which the document relates.

The above-mentioned features make the language of legal discourse not only extremely difficult (even for 
native speakers who have no legal education), but often incomprehensible.

Articulation of the purpose and objectives of the article. Translation of legal discourse implies considerable difficulties closely related to the nature of legal discourse and the specific features of English and Ukrainian legal systems and languages. The aim of the article is to study grammatical difficulties while translating legal texts. Among such grammatical difficulties, it is possible to lay emphasis on the following:

1. Difficulties related to differences in the structure of languages, their grammatical categories, forms and constructions, and in the sentence construction. This is due to the fact that English and Ukrainian belong to different branches of the Indo-European family of languages and different structural types of languages. Here is an example:

Member States shall accord nationals of other Member States the same treatment as their own nationals as regards participation in the capital of companies or firms within the meaning of the second paragraph of Article III-27, without prejudice to the application of the other provisions of the Constitution (Eurodocs) - Без порушення застосування інших положень Конституиіï, держави-члени в питаннях їхньої участі в капіталі товариств у сенсі статті III-27, надають громадянам інших держав-членів однаковий режим із власними громадянами (Eurodocs).

2. Difficulties caused by the use of non-standard sentence structure in English-language legislative discourse. It is known that legal English has significantly been influenced by the grammatical structures of French. Quite common are the varieties of the conditional mood which have fallen out of use in modern English, especially in colloquial English, for example:

Be it enacted by the Queen's most Excellent Majesty, by and with the advice and consent of the Lords Spiritual and Temporal, and Commons, in this present Parliament assembled, and by the authority of the same... (Eurodocs).

It can be argued that lawyers cannot expect translators to create parallel texts that are identical in influence, but they expect that the translated texts will have identical legal consequences. The quality of legal translation in some way affects the effectiveness of law enforcement, the degree of regulation of specific relations, so the language of translation should ensure the implementation of public purpose. This requires from the translator an absolutely clear understanding of the situational, social, contextual rules followed in the law-making process by the legislator of another state and another culture.

Presentation of the core material of the study. The system of logical connections, reflected in grammar, is universal. When learning a foreign language, we automatically compare the already known language tools to express grammatical meanings, with the tools of a foreign language. Thus the grammatical system of a foreign language is built, which in our consciousness is connected with the grammatical system of the native language. As a rule, the grammatical meanings of one language correspond to the grammatical meanings of another language. The present tense form of a verb in English corresponds to the present tense form of a verb in Ukrainian, French, German, and other languages; the contracting reason in each language also has a correspondence. Therefore, in most cases there is no great need to speak about significant obstacles. In the language system, most grammatical meanings have their correspondences. Though, it is important to understand that compliance does not mean formal identity. Linguistic competence presupposes full knowledge of these correspondences. We have a particular interest in those special cases in grammar which lie in the field of translation competence and require translation decisions.

1. Such difficulties arise in the following cases:

If there is no given grammatical meaning in the language of translation (it is not explained).

2. If there are differences in the structure of grammatical meaning in the language system, in its conventional and functional range in language implementation, including:

a) if the grammatical meaning has several forms of expression in the language of translation and the translator has to make a choice in the language implementation;

b) if the traditions of quantitative use of this grammatical form differ;

c) if the grammatical meaning is included in the meaningful invariant.

These considerations allow us to draw two general conclusions:

-We can consider as grammatical problems of translation only those problems that are in the field of translation, not language competence.

- Translation solutions related to the grammatical problems of translation include both variant correspondences and different types of transformations, including complex one- and multi-level compensation.

Considering the official business language style, it should be noted that this style is characterized by a large number of terms and concepts. In the range of language tools and techniques, the main features of the official business style are the consistency and accuracy of the facts, clarity, monosemanticity and conciseness of statements, the presence of set verbal formulas (for example, to, in connection with, in accordance with, in order, according to, etc.), the use of words in the literal sense, the widespread use of special terms, the observance of the direct order of words in a sentence, etc. Official business style is expressively neutral because it emphasizes business relationships and does not convey a subjective assessment of what is being taught. In the official business style it is very important to adhere to the following grammar rules:

1. It is necessary to limit the use of complex syntactic constructions of sentences with adjectives and adverbial expressions, with different kinds of remarks.

2. Conciseness of the statement is achieved by replacing complex sentences with simple ones, as well as by eliminating adjectives and adverbial expressions and using common abbreviations.

3. The use of impersonal and imperative forms of the verb in the present tense with the indication of priority or regularity of action.

4. The use of complex sentences with conjunctions and subjunctives should be minimized; asyndetic, simple 
sentences are used instead (several subjects in one predicate, several predicates in one subject, several objects in one of the main parts of the sentence, etc.).

When translating texts of official business style, we encounter a number of grammatical difficulties whose reasons for existence are primarily differences in the picture of the world of English and Ukrainian languages. The stability and clarity of sentence construction helps to easily recognize the transformations and constructions that take place in the original texts and their equivalents. However, in some cases, when confronted with the terminology of official business style texts, it is necessary to be able to adequately select a certain type of translation. That is why, when researching the translation of official business style texts, it is very important to note which constructions are used most often and which method of material transfer should be used in a given situation.

The most commonly used grammatical transformations in the translation of legal texts include the following:

- Replacement of the singular with the plural:

State Parties recognize the right of the child to the enjoyment of the highest attainable standard of health... (Eurodocs)-Держави-учаснииі визнають право дитини на користування найдосконалішими існуючими послугами системи охорони здоров'я... (Eurodocs).

- Replacement of parts of speech:

...to this end, State Parties shall promote the conclusion of bilateral or multilateral agreements or accession to existing agreements (Eurodocs) - ...3 uіiєю метою держави-учасниці сприяють укладанню двосторонніх чи багатосторонніх угод або приєднуються до чинних угод (Eurodocs).

In this case, the English noun 'accession' was replaced by the verb 'join' in the Ukrainian sentence.

- Changing the order of words in a sentence:

State Parties shall take all appropriate measures to ensure to women, on equal terms with men and without any discrimination, the opportunity... (Eurodocs) - Держави-учасниці вживають усіх відповідних заходів, щзоб забезпечити жінкам можливість на рівних умовах з чоловіками $i$ без будь-якої дискримінації... (Eurodocs).

- Translation of gerundial constructions:

No State Party shall expel, return or extradite a person to another State where there are substantial grounds for believing that he would be in danger of being subjected to torture (Eurodocs) - Жодна держава-учасниця не повинна висилати, повертати чи видавати будь-яку особу іншій державі, якщуо $є$ серйозні підстави вважати, щчо ій там може загрожувати застосування катувань (Eurodocs).

- Sentence segmentation:

The provision for the reduction of inc stillbirth-rate and of infant mortality for the healthy development of the child and the improvement of all aspects of environmental and industrial hygiene (Eurodocs) Забезпечення скорочення мертвонароджуваності та дитячої смертності і піклування про здоровий розвиток дитини. Поліпшення всіх аспектів гігієни зовнішнього середовищуа $i$ гігієни праці в промисловості (Eurodocs).
- Sentence combining:

No one shall be subjected to torture or to cruel, inhuman or degrading treatment or punishment. In particular, no one shall be subjected without his free consent to medical or scientific experimentation (Eurodocs) - Нікого не може бути піддано катуванню чи жорстокому, нелюдському або принижуючому гідність поводженню, а також жодну особу не може бути без ї̈ добровільної згоди піддано медичним чи науковим дослідам (Eurodocs).

As S. Postryhan denotes, an institutional legal text is a message of governmental nature objectified in the form of a written document concluded by the subject of a certain social and legal institution in a certain culture, which focuses on a certain range of recipients. Such a document has a special semantic unity, which is determined by its inherent types of lexical, grammatical, logical and legal connections, as well as semantic completeness and pragmatic guidance [4].

Depending on the type of documents being translated, legal translation is divided into translation of laws and regulations and their drafts, translation of contracts, translation of legal opinions and memoranda, translation of apostilles and notarial certificates, translation of constituent documents of legal entities and translation of powers of attorney.

Legal translation as a creative process of high degree of complexity largely consists of finding equivalents between the different types of categories of the original text and the translated text. The main characteristics of the institutional legal text, according to the researchers $[1,7]$, are brevity, unification, logic and argumentation of presentation, impersonality, accuracy of wording, conservatism, extreme clarity of statements, and fixed macrostructure of individual text genres.

Thus, I. Korunets, comparing legal texts with texts of other functional styles, notes that legal documents lack emotionality, interrogative and exclamatory modalities, dialogical and monologue forms of presentation, they are dominated by the use of verbs in the present tense, and they also comprise a large number of standardized international clichés [3, 290].

As I. Rud notes [5, 222-225], such clichés include, i.e., constructions of type

(1) hereinafter referred to as 'the Parties' - якi надалі іменуються Сторони; and type (2) have agreed as follows - домовилися про таке, are characteristic of the genre 'contract'. Other genres of legal discourse are dominated by clichés directly related to the macrostructure of the document. For example, (3) for the purpose of this agreement - y uүй угодi the following terms have such meaning. This cliché is used in the main part of legal texts of the genre 'international agreement', (4) done at ... on the... day of ... in the year ..., in duplicate each in the English and Ukrainian languages, each of these texts being equally authentic - вчинено y (number denoted by ordinal numbers)... day... (name of the month)... (year denoted by ordinal numbers) of the year in two copies, each in Ukrainian and English, all texts being authentic. This formula is a standardized final part of agreements and treaties in international law. Let us consider more in detail the typical interlingual differences for the language pair 
'English-Ukrainian' at the syntactic and morphological levels in the case of translation of legal texts of institutional legal discourse. One of the defining grammatical features of legal documents is the use of complex modal predicates shall + Infinitive:

(5) Diplomatic missions and consular posts of the Member States shall issue multiple-entry visas $<\ldots>$ to the following categories of persons $<\ldots>$ (mfa.gov.ua) Дипломатичні представництва та консульські установи держав-членів оформлюють багаторазові візи < .. > таким категоріям осіб < .. > (mfa.gov.ua)

(6) "Member State" shall mean any Member State of the European Union (mfa.gov.ua) - «Держсава-член» означає будь-яку державу-члена Європейського Союзу <...> (mfa.gov.ua)

Examples 5 and 6 of the text genre 'international agreement' demonstrate that such a complex predicate shall + Infinitive is translated into Ukrainian by the Ukrainian verb in the active voice in the present tense. However, if the negative particle not is added to the specified complex modal predicate, then there will be another version of translation with the Ukrainian complex modal predicate in the sense of prohibition:

Typical complex modal predicates in legal texts of the genre 'international agreement' can also include may/may not+Infinitive, which indicate the permission or prohibition of certain actions of the parties, for example:

(9) Citizens of the European Union and of Ukraine who have lost their identity documents $\langle\ldots\rangle$, may leave the territory of Ukraine or the Member States on the grounds of valid identity documents $<\ldots>$ issued by diplomatic missions or consular posts of Ukraine or the Member States <...> (Eurodocs) - Громадяни України та Свропейського Союзу, які втратили документи, щчо посвідчують іх особу, можуть залишити територію України або держав-членів на підставі оформлених їм дипломатичними представництвами або консульськими установами України або держав-членів дійсних документів, щуо посвідчують їхню особу $<\ldots>$ (Eurodocs).

According to Grammar researcher O. Yemelina, the grammatical features of the translation of legal texts include: the predominance of present tense verbs, passive constructions, modal verbs to denote necessity and possibility, the absence of personal and indicative pronouns, the transfer of numerals in words, and the use of Latin clichéd forms. It is also worth mentioning the lack of emotional coloring and complex syntax, which helps to achieve accuracy and unambiguous legal wording [2]. As far as the grammatical structure of language reflects a system of logical connections through which the world around is perceived and described, the grammatical structure is largely decisive for the process of translation to convey semantic content. In the case of legal translation, the content of the text imposes certain restrictions on the grammatical constructions of the language, which can be overcome by using grammatical transformations. Such techniques include changing the word-order, changing the structure of the sentence (completely or partially, replacing parts of speech and members of the sentence, adding and omitting words) can be used separately. However, quite frequently, when translating the same sentence several techniques can be used simultaneously. In English sentences, the semantic center can be both at the beginning and at the end of the sentence, while in Ukrainian the semantic center is at the end of the sentence. The Ukrainian language allows to identify the semantic center at the expense of use of more flexible wordorder and, most frequently, the order of words will be reversed: secondary members, a predicate, a subject. The presence of the definite article in front of the subject shows that the subject does not carry new information; therefore, the semantic center is at the end of the sentence. In this case, the order of words in translation is not changed as the place of the semantic center in English and Ukrainian sentences coincides. The indefinite article implies the presence of new information, therefore, the place of the semantic center of Ukrainian and English sentences does not coincide, which makes it necessary to change the order of words in translation:

The present Agreement shall come into effect from the date hereof and its validity term shall not be defined (Eurodocs) - Цей договір вступає в силу з дня підписання його Сторонами $і$ діє протягом невизначеного терміну (Eurodocs).

Replacement of parts of speech and members of a sentence. The use of personal and impersonal verb forms is a characteristic feature of the English language, while the Ukrainian language is characterized by a wider use of nouns:

An external manager is authorized to conserve the debtor's estate, monitor the activities of the debtor's management, equally distribute debtor's assets among its creditors in case of the liquidation of the debtor and terminate the bankruptcy case (Eurodocs) У число повноважень розпорядника майна входять: забезпечення збереження майна компанії-боржника, спостереження за діяльністю керівництва такого підприємства, відповідне розподілу майна боржника між його кредиторами у разі ліквідації або припинення справи про банкрутство (Eurodocs).

Considerable difficulties arise when we deal with the translation of verbs in the passive voice, especially in constructions with a single subject. As a rule, in the sentences with one subject there can appear several predicates in the Passive and Active Voices. When translating such sentences in the process of transformation, such a passive form is translated lexically.

The company may on its own behalf acquire and exercise property and non-property rights, perform duties, sue and be sued in courts (Eurodocs) - Компанія має право від свого імені набувати і здійснюватимайнові та особисті немайнові права, нести обов'язки, бути позивачем і відповідачем в суді (Eurodocs).

Adding and omitting words. Due to the inherent conciseness of the English language when translating into Ukrainian, a need to add words frequently arises. Omission of words in translation is much less common.

Under contract law, there is no contract if there is nо consideration (Eurodocs) - В рамках договірного права договір не може існувати без зустрічного задоволення (Eurodocs).

Conclusions and prospects for further research in this field. Thus, taking into account the fact that legal translation is one of the most complex types of trans- 
lation, which requires a high level of professionalism, it should be noted that it is not enough for the translators to use their basic skills. Legal translation cannot be carried out correctly without the use of special knowledge in the relevant field of law, without knowledge of the specifics of a particular type of legal relationships. It is necessary to know much about the current legislation, and also to possess a set of special skills on understanding the subtleties of grammatically correct translation of the legal text / discourse. As legal translation is one of the most popular types of translation today, there is a growing demand for translators who specialize in this field. Legal linguistics is a relatively new, but not well developed science yet. Thus the specifics of legal translation are insufficiently studied and need more in-depth analysis. Different approaches of scholars to understanding grammatical features in the translation of a legal text were considered, so the use of considered and analyzed grammatical translation transformations of a legal nature in the process of transmitting English texts is a necessary condition for solving the problem of literacy and accuracy.

The considered examples show that grammatical transformations and knowledge of the peculiarities of the structure of a legal text are important translation tools for adequate transmission of the information content of the text. However, when translating legal texts, one should not forget that each country has its own legal system, relevant legal terminology and practice. Therefore, the correct use of this tool is difficult without studying the linguistic grammatical features, which is the basis for the textual design of legal texts and documents.

\section{BIBLIOGRAPHY}

1. Гладуш Н. Ф. Концепція перекладу в працях сучасних англійських перекладознавців. Актуальні проблеми перекладознавства та навчання перекладу в мовному ВУЗі : тези доповідей. Київ : Вид. центр КНЛУ, 2006. С. $43-44$.

2. Емелина О. В. Грамматические особенности перевода юридических текстов. Право и управление. XXI век. 2011. Вип. 2. С. 70-73.

3. Корунець І. В. Вступ до перекладознавства : підручник. Вінниця : Нова Книга, 2008. 512 с.

4. Постриган С. В. Усталені словосполучення в німецькому інституційному юридичному тексті: лінгвокультурологічний та комунікативно-прагматичний аспекти : автореф. дис. на здобуття наук. ступ. канд. філол. наук : 10.02 .04 . Київ, 2009. 17 с.

5. Рудь I. В. Граматичні труднощі перекладу юридичних документів (на матеріалі: «міжнародних угод» англійською мовою) : вебсайт. URL: http://philology.knu.ua/library/zagal/Movni_i_konceptualni_2010_30/222_226.pdf.8.

6. Семьонкіна I. А. Специфіка англомовного законодавчого дискурсу в аспекті перекладу. Вісник Харківського начіонального університету ім. В. Н. Каразіна. 2010. Вип. 896 : Романо-германська філологія. Методика викладання іноземних мов. Вип. 61. С. 181-185.

7. Снелл-Хорнбі М. Перекладознавство. Інтегрований підхід. Амстердам, Філадельфія, 1999. 166 с.

\section{SOURCES OF ILLUSTRATIVE MATERIAL}

8. Eurodocs - Свропейська спільнота, Україна. Угода між Україною та Європейськими Співтовариствами. Електронна система документаиії з питань адаптаџії законодавства України до Законодавства Європейського союзу : вебсайт. URL: eurodocs.sdla.gov.ua.

9. mfa.gov.ua - Європейське Співтовариство, Україна. Угода між Україною та Свропейським Співтовариством (Свропейським Союзом) про сприяння видачі віз. Офісний журнал Свропейського Союзу. 2007 : вебсайт. URL: http://mfa.gov.ua/mediafiles/sites/ukraine-eu/files/on_the_facilitation_of_the_issuance_of_ visas.pdf.

\section{REFERENCES}

1. Hladush, N. F. (2006). Kontseptsiia perekladu v pratsiakh suchasnykh anhliiskykh perekladoznavtsiv [The concept of translation in the works of modern English translators]. Aktualni problemy perekladoznavstva ta navchannia perekladu $v$ movnomu VUZi. Abstracts. Kyiv: Center of KNLU, 43-44 [in Ukrainian].

2. Yemelina, O. V. (2011). Hrammatycheskye osobennosty perevoda yurydycheskykh tekstov [Grammatical features of translation of legal texts]. Pravo y upravlenye. XXI vek, 2, 70-73 [in Russian].

3. Korunets, I. V. (2008). Vstup do perekladoznavstva [Introduction to translation studies]: pidruchnyk. Vinnytsia: Nova knyha [in Ukrainian].

4. Postryhan, S. V. (2009). Ustaleni slovospoluchennia v nimetskomu instytutsiinomu yurydychnomu teksti: linhvokulturolohichnyi ta komunikatyvno-prahmatychnyi aspekty [Set expressions in the German institutional legal text: linguocultural and communicative-pragmatic aspects]. (Avtoreferat dysertatsii kandydata filolohichnykh nauk). Kyiv [in Ukrainian].

5. Rud, I. V. (2010). Hramatychni trudnoshchi perekladu yurydychnykh dokumentiv (na materiali: "mizhnarodnykh uhod" anhliiskoiu movoiu) [Grammatical difficulties of translation of legal documents (on the materials: "international agreements" in English)]. URL: http://philology.knu.ua/library/zagal/Movni_i_konceptualni_2010_30/222_226.pdf.8.

6. Semyonkina, I. A. (2010). Spetsyfika anhlomovnoho zakonodavchoho dyskursu v aspekti perekladu [Specificity of English legislative discourse in the aspect of translation]. Visnyk Kharkivskoho natsionalnoho universytetu im. V. N. Karazina. Kharkiv, 896: Romano-hermanska filolohiia. Metodyka vykladannia inozemnykh mov, 61, 181-185 [in Ukrainian].

7. Snell-Hornby, M. (1992). Perekladoznavstvo. Intehrovanyi pidkhid [Translation Studies. An Integrated Approach]. Amsterdam, Philadelphia [in Ukrainian]. 


\section{SOURCES OF ILLUSTRATIVE MATERIAL}

8. Eurodocs - Yevropeiska spilnota, Ukraina. Uhoda mizh Ukrainoiu ta Yevropeiskymy Spivtovarystvamy [European Community, Ukraine. Agreement between Ukraine and the European Communities.]. Elektronna systema dokumentatsii z pytan adaptatsii zakonodavstva Ukrainy do Zakonodavstva Yevropeiskoho soiuzu. Retrieved from: eurodocs.sdla.gov.ua.

9. mfa.gov.ua - Yevropeiska spilnota, Ukraina. Uhoda mizh Ukrainoiu ta Yevropeiskym spivtovarystvom (Yevropeiskym Soiuzom) pro spryiannia vydachi viz [European Community, Ukraine. The Agreement between Ukraine and European Communities (European Union) on facilitation of the issuance of visas]. Official Journal of the European Union, 2007. Retrieved from: http://mfa.gov.ua/mediafiles/sites/ukraine eu/files/on_the_facilitation_of_the_issuance_of_visas.pdf. 